\title{
IMMUNOMODULATORY ROLE OF VITAMIN D: CLINICAL IMPLICATIONS IN INFECTIONS AND AUTOIMMUNE DISORDERS
}

\author{
Farhan Khashim Alswailmi', Syed Imran Ali Shah ${ }^{1}$, Haleema Nawaz ${ }^{2}$ \\ ${ }^{1}$ College of Pharmacy, University of Hafr Al-Batin, Hafar Al-Batin, Saudi Arabia, ${ }^{2}$ Department of Biochemistry, \\ Central Park Medical College, Lahore, Pakistan
}

\begin{abstract}
Vitamin D exerts its well-known effects on bone health and calcium-phosphate homeostasis primarily through the vitamin D receptor signaling pathway. Vitamin D also has several extra-skeletal actions and its deficiency is not only implicated in musculoskeletal disorders, but also cardiovascular disorders, diabetes, neurodegenerative conditions and cancers. There is a growing body of research highlighting the link of vitamin D deficiency and alterations in vitamin D signaling with certain infections and autoimmune disorders; although the evidence is inconsistent and inconclusive. Vitamin $\mathrm{D}$ has been suggested to play a fundamental role in curbing infections and mitigating autoimmune disease processes. The present review was undertaken to explore the promise of vitamin $\mathrm{D}$ as a protective agent and a clinically useful therapeutic adjunct against infections and autoimmune diseases and identify knowledge gaps and limitations of the available data for informing future work. An exhaustive search was conducted in established databases including Google Scholar, PubMed, ScienceDirect and Springer for articles published on vitamin D, immunity, infection and autoimmune disorders. All relevant articles published in the English language between the year 2000 and 2020 were retrieved for writing the review. Although a considerable body of evidence highlighting the potential clinical benefits of vitamin D against the development of various autoimmune conditions and for the prevention of infections has emerged over the last decade, the findings are limited by the lack of appropriately designed randomized controlled trials which are needed to formulate precise clinical recommendations.
\end{abstract}

KEY WORDS: Vitamin D; Immunity; Infection; Vitamin D Receptors; Vitamin D Deficiency; Autoimmune Diseases; Calcitriol; Cholecalciferol; Multiple Sclerosis; Neuroprotection.

Cite as: Alswailmi FK, Shah SIA, Nawaz H. Immunomodulatory role of Vitamin D: clinical implications in infections and autoimmune disorders [review article]. Gomal J Med Sci 2020 Jul-Sep; 18 (3):132-8. https://doi.org/10.46903/ gjms/18.03.841

\section{INTRODUCTION}

Vitamin D (calciferol), a fat-soluble vitamin, is primarily involved in the maintenance of skeletal health and mineral homeostasis. Vitamin $D$ is a steroidal organic compound having two major naturally occurring forms, ergocalciferol in plants and cholecalciferol in animals. Vitamin $\mathrm{D}$ has hormone-like actions and its chief target organs are the bone, kidney and small intestine where it regulates calcium and phosphorus absorption and metabolism. ${ }^{1}$ Endogenous dermal

\section{Corresponding Author:}

Dr. Syed Imran Ali Shah

College of Pharmacy

University of Hafr Al-Batin, Hafar Al-Batin,

Saudi Arabia

E-mail: simranali@uhb.edu.sa

Date Submitted: $\quad 11-06-2020$

Date Revised: 20-06-2020

Date Accepted: $\quad 28-06-2020$ production is the principal human source of vitamin D while exogenous dietary contribution is much smaller. ${ }^{2}$ Skin exposure to natural sunlight leads to conversion of the cholesterol derivative 7-dehydrocholesterol into vitamin D3. Vitamin D3 then undergoes hydroxylation in the liver at position 25 and then in the kidney at position 1 to form the active metabolite 1,25-dihydroxy D3 (calcitriol). ${ }^{3}$

Besides skeletal mineral balance, vitamin $D$ has been shown to be involved in multiple extra skeletal functions including neuroprotection, xenobiotic detoxification, cell proliferation, cellular differentiation and immunomodulation. ${ }^{4}$ These findings have highlighted the potential of vitamin D as an antioxidant, anticancer, antimicrobial and anti-inflammatory agent having a tremendous impact on the health of the musculoskeletal, cardiovascular, nervous and immune systems. These pleiotropic actions of vitamin $D$ are carried out via the vitamin $D$ receptors (VDR) that belong to the nuclear hormone receptor 
family and are present on various cell types such as cells involved in immune functions. ${ }^{5,6}$ Vitamin D has important functional roles in immunity, at the level of both innate and adaptive immune systems. The suppression of antigen-presenting cell (APC) maturation and reduction of pro-inflammatory cytokines are few of the well-known immunomodulatory features of vitamin $\mathrm{D} .{ }^{7}$ The deficiency of vitamin $\mathrm{D}$ has been related to many immune diseases like asthma, psoriasis, rheumatic diseases, and multiple sclerosis. Normal vitamin $\mathrm{D}$ levels have been reported to play part in protection against certain viral and bacterial infections.

\section{VITAMIN D AND INFECTION}

Vitamin $D$ deficiency is reported to be associated with an increased risk of infections. Seasonal changes in the levels of vitamin D are associated with an increased incidence of several infections, particularly respiratory infections, in many epidemiologic studies. Moreover, considering the emerging evidence on the modulatory mechanisms employed by vitamin D on immune functions, the benefits of vitamin D supplementation against infectious processes come as no surprise. ${ }^{8}$

\section{Influenza A viral infection}

Low serum levels of vitamin $D$ during winter are reported to be associated with the increased occurrence of epidemic influenza. ${ }^{9}$ Low incidence of influenza A viral infection has been shown in school-going children upon supplementation with $1200 \mathrm{lUs}$ of vitamin D3 daily. ${ }^{10}$ However, in other populations, the amount of vitamin $\mathrm{D}$ needed to derive clinical benefits remains rather vague. ${ }^{11}$ Some clinical practices have reported complete resolution of influenza symptoms within two to three days of a one-time 50,000 IU dose of vitamin D3. ${ }^{12}$ Supplementation with vitamin D3 is potentially advantageous in conditions in which influenza vaccine is contraindicated such as in patients receiving immunosuppressive therapy. ${ }^{13}$ Therefore, it is not too early to suggest health care providers to promptly diagnose and treat vitamin $\mathrm{D}$ deficiency in deficient patients. ${ }^{14}$

\section{Tuberculosis}

Heliotherapy (sunlight exposure) and subsequently cod liver oil and vitamin D (following its isolation from cod liver oil almost a century ago) were historically used as therapy and prophylaxis for tuberculosis. ${ }^{8,15}$ Tuberculosis has been linked with vitamin $\mathrm{D}$ deficiency and VDR polymorphisms which make these populations particularly susceptible to the ailment. ${ }^{16-18}$ Progression of TB in affected individuals has a strong correlation with serum vitamin $D$ levels. ${ }^{19}$ This may be explained by the bactericidal action of vitamin D against Mycobacterium tuberculosis such as reversal of mycobacterium tuberculosis-induced inhibition of phagosome maturation, which is an important element of progression of tu- berculosis. ${ }^{15}$ Vitamin $D$ may serves as a beneficial adjunct to antibiotic regimens aimed against $\mathrm{MycO}-$ bacterium tuberculosis and its multi-drug resistant form. . $^{20,21}$

\section{Other bacterial infections}

Keeping in view the antimycobacterial actions and inhibitory effect of vitamin D on the pathogenesis of tuberculosis, it is safe to assume a role of vitamin D in the prevention, inhibition and treatment of other infections. Vitamin D3 has been shown to control pulmonary inflammation by inducing the production of cathelicidin, which is dubbed as the natural broad-spectrum antimicrobial peptide. ${ }^{13}$ Acute respiratory infections, particularly in children, are reported to be more commonly seen with vitamin $\mathrm{D}$ deficiency, and supplementation has not been clearly indicated as an effective prevention strategy against acute respiratory infections. ${ }^{22}$ Seasonal disparities in circulating vitamin D parallel those of sepsis. ${ }^{23}$ Vitamin $D$ has also been reported as an effective intervention in treating Helicobacter pylori infections. ${ }^{24}$ Such studies thus highlight the need to verify and establish additional correlates of vitamin $D$, and investigate it in the context of infectious processes.

Sufficient information is not there about the immunomodulatory potential of vitamin $\mathrm{D}$ in fungal, protozoal, or parasitic infections. Low dose vitamin D is reported to reduce fungal burden and improve survival in candida-infected mice but higher doses were associated with poor outcomes. ${ }^{25}$ Emerging evidence alludes to the fact that vitamin D status has a significant contribution to the overall immune response and vitamin $D$ repletion can potentially offer favorable outcomes against multiple microbial pathogens. ${ }^{8}$

\section{VITAMIN D AND AUTOIMMUNE DISEASE}

The involvement of vitamin $D$ in immune response modulation makes it a pivotal element in some autoimmune diseases like multiple sclerosis, type 1 diabetes mellitus, psoriasis, inflammatory bowel disease, systemic lupus erythematosus and rheumatoid arthritis. ${ }^{26}$ Patients having autoimmune diseases have been revealed to have lower serum concentrations of vitamin $D$ than the general population..$^{27-30}$ This suggests that vitamin $D$, in contrast to genetic and some environmental factors, may be a modifiable element in the development of autoimmunity. Here, we review some of the well-known autoimmune conditions which have been associated with vitamin $\mathrm{D}$ deficiency.

\section{Systemic lupus erythematosus}

Systemic lupus erythematosus (SLE), an autoimmune disorder with a chronic course, is capable of affecting virtually any organ system. ${ }^{31}$ Although the exact underlying mechanism for SLE development is not yet fully understood, mounting evidence sug- 
gests an association between SLE and hypovitaminosis D. ${ }^{32-34}$ Other studies also report quicker SLE progression in patients having low serum levels of vitamin D. ${ }^{35-37}$ This is especially discommodious for SLE patients who are required to avoid sun exposure, thus worsening the already present vitamin $\mathrm{D}$ deficiency. Lower disease activity has been witnessed in patients given vitamin D supplements. ${ }^{38,39}$ However, a practical strategy to integrate vitamin D supplementation into SLE treatment has not been developed so far.

\section{Multiple sclerosis}

The autoimmune diseases multiple sclerosis (MS) is a chronic debilitating condition targeting the nervous system. MS has previously been linked with vitamin D in several epidemiologic and observational studies. ${ }^{40-42}$ Better exposure to the sun and higher vitamin $D$ levels in childhood and adolescence are reported to decrease the risk of developing MS later in life. ${ }^{43-47}$ Low serum vitamin $D$ levels at the time of diagnosis has been shown to be affiliated with early conversion of relapsing-remitting course to secondary progressive disease. ${ }^{48}$ Vitamin D supplementation causes significant alleviation of symptoms and improvement of overall health in patients with relapsing-remitting MS. ${ }^{49}$ Vitamin D thus appears to have the potential to improve MS prognosis.

\section{Type 1 diabetes mellitus}

Association of vitamin $\mathrm{D}$ status with type 1 diabetes mellitus (T1DM) is well-documented, with early vitamin $D$ supplementation in genetically predisposed infants and children possibly reducing the risk of developing T1DM..$^{50-52}$ Some studies have found vitamin $\mathrm{D}$ to be a useful adjunct to insulin therapy in T1DM patients..$^{53-55}$ Randomized controlled trials (RCTs) with supplementary vitamin D have reported positive short-term effects in recently diagnosed T1DM patients. ${ }^{56}$ Vitamin D is most certainly a valuable area of research in the context of T1DM treatment and warrants further research.

\section{Inflammatory bowel disease}

Inflammatory bowel disease (IBD), a Th1-immune mediated autoimmune disorder, is characterized largely by vitamin $\mathrm{D}$ deficiency. ${ }^{57}$ However, this deficiency does not indicate a cause and effect relationship, and may just be a result of malabsorption or decreased vitamin D intake secondary to IBD. Although, some murine models have shown promising effects on IBD symptoms and complications upon vitamin $D$ supplementation, ${ }^{58-60}$ human based studies have yet to confirm these hypotheses. ${ }^{61}$

\section{Rheumatoid arthritis}

Rheumatoid arthritis (RA) is a multifactorial chronic inflammatory and autoimmune condition characterized by articular and extra-articular destruction that can lead to dysfunction and permanent disability. Some studies have demonstrated serum vitamin D to be inversely correlated with RA susceptibility and disease activity. ${ }^{62}$ Vitamin $D$ deficiency alongside other genetic and environmental determinants may trigger the onset and progression of RA but conclusive evidence is lacking. ${ }^{63-68}$ Results from a recent study did not indicate a link between circulating vitamin $D$ levels and future risk of RA. ${ }^{69}$ Further data need to be gathered and analyzed in order to consider vitamin $\mathrm{D}$ as a low-risk and cost-effective adjunct to RA treatment.

\section{Uveitis}

Uveitis is an inflammatory ophthalmologic disease which affects the retina and uvea, and its etiopathogeneis predominantly involves T-lymphocyte mediated autoimmune damage. ${ }^{70}$ The potential benefits of vitamin $D$ have been highlighted in the context of this sight-threatening autoimmune condition. Serum vitamin $D$ levels within the normal range are associated with a reduced incidence of noninfectious uveitis, suggesting an increased risk of uveitis with hypovitaminosis D. ${ }^{71}$ Inadequate vitamin D status predisposes to a higher risk of autoimmune anterior uveitis, with a $4 \%$ risk reduction for every $1 \mathrm{ng} / \mathrm{mL}$ rise in serum vitamin D. ${ }^{71}$

Another recent study by Chiu, et al. showed that patients having active uveitis had lower circulating vitamin $D$ than those having inactive uveitis. Supplementation with vitamin $\mathrm{D}$ and solar exposure were shown to decrease uveitis activity in patients with hypovitaminosis $D .^{72}$ Supplementary vitamin D also offers beneficial effects in the course of autoimmune uveitis, regardless of circulating vitamin $D$ levels. ${ }^{73}$ Vitamin $D$ deficiency is a common finding in juvenile idiopathic arthritis (JIA), and it is associated with higher disease activity and risk of uveitis. ${ }^{74}$ Future prospective studies are required to inform about the potential use of vitamin D supplementation as an adjunctive therapy in the community prevention and/ or clinical treatment of autoimmune uveitis.

\section{Dermal autoimmune conditions}

Topical vitamin D analogues combined with corticosteroids, and otherwise, have long been used safely and effectively for treating inflammatory skin diseases such as psoriasis. . $^{29,75,76}$ Low serum vitamin $D$ levels are also been linked to atopic dermatitis and vitiligo. ${ }^{77,78}$ However, further evidence from multi-nuclear case-control studies is needed to ascertain whether vitamin $\mathrm{D}$ contributes to the increased risk of developing these conditions, and whether or not supplementation can be used in disease treatment.

\section{CONCLUSION}

Vitamin D, through its regulatory effects on immunity, shows irrefutable promise in the context of autoimmune and infectious disease treatment and prevention. However, current studies are limited by compromised study designs, small sample 
sizes, selection bias, time constraints and lack of resources, among others. Investigation of the immune mechanisms activated by vitamin $\mathrm{D}$ is needed to emphasize its potential immunomodulatory benefits. Furthermore, the clinical utility of vitamin $D$ in the setting of immune disorders needs to be substantiated through randomized controlled trials. This review highlights viable evidence that necessitates conducting more comprehensive studies that may allow vitamin $D$ supplementation to be used as a safe, effective and inexpensive tool for curbing and mitigating a plethora of infectious and autoimmune diseases.

Acknowledgement: The authors extend their appreciation to the Deanship of Scientific Research, University of Hafr Al-Batin for funding this work through the research group project No. G-103-2020.

\section{REFERENCES}

1. Buyuker SM. Vitamin D deficiency and toxicity. Eurasian J Med Oncol 2019;3(1):1-5. https://doi. org/10.14744/ejmo.2018.0049

2. Gil A, Plaza-Diaz J, Mesa MD. Vitamin D: classic and novel Actions. Ann Nutr Metab 2018;72:8795. https://doi.org/10.1159/000486536

3. Christakos S, Bikle D. New aspects of vitamin D metabolism and action - addressing the skin as source and target. Nat Rev Endocrinol 2020;16:234-52. https://doi.org/10.1038/s41574019-0312-

4. Shah SIA. Beneficial role of vitamin D in common cancers: Is the evidence compelling enough? World Cancer Res J 2020;7:e1574.

5. Lockau L, Atkinson SA. Vitamin D's role in health and disease: How does the present inform our understanding of the past? Int J Paleopathol 2018;23:6-14. https://doi.org/10.1016/j. ijpp.2017.11.005

6. Zmijewski MA. Vitamin D and human health. Int J Mol Sci 2019;20:145. https://doi.org/10.3390/ ijms20010145

7. Trombetta AC, Paolino S, Cutolo M. Vitamin D, inflammation and immunity: Review of literature and considerations on recent translational and clinical research developments. Open Rheumatol J 2018;12(1):201-13. https://doi.org/10.2174/187 4312901812010201

8. Yamshchikov AV, Desai NS, Blumberg HM, Ziegler TR, Tangpricha V. Vitamin D for treatment and prevention of infectious diseases: a systematic review of randomized controlled trials. Endocr Pract 2009;15(5):438-49. https://doi.org/10.4158/ EP09101.ORR

9. Cannell JJ, Vieth R, Umhau JC, Holick MF, Grant WB, Madronich S, et al. Epidemic influenza and vitamin D. Epidemiol Infect 2006;134(6):1129-40. https://doi.org/10.1017/S0950268806007175

10. Urashima M, Segawa T, Okazaki M, Kurihara M, Wada Y, Ida H. Randomized trial of vitamin D sup- plementation to prevent seasonal influenza $A$ in schoolchildren. Am J Clin Nutr 2010;91(5):125560. https://doi.org/10.3945/ajcn.2009.29094

11. Lang PO, Aspinall R. Vitamin D status and the host resistance to infections: What it is currently (not) understood. Clin Ther 2017;39(5):930-45. https:// doi.org/10.1016/j.clinthera.2017.04.004

12. Schwalfenberg G. Vitamin D for influenza. Can Fam Physician 2015;61:507.

13. Shalayel MHF, Al-Qahtani AM, Huneif MA. Vitamin $D$ or flu vaccine - benefits over adverse effects. British Biomed Bulletin 2018;6(1):311. https://doi. org/10.21767/2347-5447.1000311

14. Gruber-Bzura BM. Vitamin D and influenza - prevention or therapy? Int J Mol Sci 2018;19(8):2419. https://doi.org/10.3390/ijms19082419

15. Ralph AP, Kelly PM, Anstey NM. L-arginine and vitamin D: novel adjunctive immunotherapies in tuberculosis. Trends Microbiol 2008;16(7):336-44. https://doi.org/10.1016/j.tim.2008.04.003

16. Wilkinson RJ, Llewelyn M, Toossi Z, Patel P, Pasvol G, Lalvani A, et al. Influence of vitamin $D$ deficiency and vitamin $D$ receptor polymorphisms on tuberculosis among Gujarati Asians in west London: a case-control study. Lancet 2000;355(9204):618-21. https://doi.org/10.1016/ S0140-6736(99)02301-6

17. Sutaria N, Liu CT, Chen TC. Vitamin D status, receptor gene polymorphisms, and supplementation on tuberculosis: A systematic review of case-control studies and randomized controlled trials. J Clin Transl Endocrinol 2014;1(4):151-60. https://doi.org/10.1016/j.jcte.2014.08.001

18. Panda S, Tiwari A, Luthra K, Sharma SK, Singh A. Association of Fok1 VDR polymorphism with Vitamin D and its associated molecules in pulmonary tuberculosis patients and their household contacts. Sci Rep 2019;9(1):15251. https://doi. org/10.1038/s41598-019-51803-8

19. Talat N, Perry S, Parsonnet J, Dawood G, Hussain R. Vitamin d deficiency and tuberculosis progression. Emerg Infect Dis 2010;16(5):853-5. https:// doi.org/10.3201/eid1605.091693

20. Yamshchikov AV, Oladele A, Leonard MK, Blumberg HM, Ziegler TR, Tangpricha V. Vitamin D as adjunctive therapy in refractory pulmonary tuberculosis: A case report. Southern Med J 2009;102:649-52. https://doi.org/10.1097/ SMJ.0b013e3181a5d37e

21. Jolliffe DA, Ganmaa D, Wejse C, Raqib R, Haq MA, Salahuddin N, et al. Adjunctive vitamin D in tuberculosis treatment: meta-analysis of individual participant data. Eur Respir J 2019;53(3). https:// doi.org/10.1183/13993003.02003-2018

22. Das RR, Singh M, Panigrahi I, Naik S. Vitamin D supplementation for the treatment of acute childhood pneumonia: A systematic review. ISRN Pediatrics 2013;2013:459160. https://doi. org/10.1155/2013/459160

23. Ahari $\mathrm{MH}$, Pishbin E. Vitamin $\mathrm{D}$ and sepsis. Rev Clin Med 2014;1 (4):225-8. 
24. Assaad S, Chaaban R, Tannous F, Costanian C. Dietary habits and Helicobacter pylori infection: a cross sectional study at a Lebanese hospital. BMC Gastroenterol 2018;18(1):48. https://doi. org/10.1186/s12876-018-0775-1

25. Lim JH, Ravikumar S, Wang YM, Thamboo TP, Ong L, Chen J, et al. Bimodal influence of vitamin $D$ in host response to systemic candida infection-vitamin $D$ dose matters. J Infect Dis 2015;212(4):635-44. https://doi.org/10.1093/ infdis/jiv033

26. Murdaca G, Tonacci A, Negrini S, Greco M, Borro M, Puppo F, et al. Emerging role of vitamin D in autoimmune diseases: An update on evidence and therapeutic implications. Autoimmun Rev 2019;18(9):102350. https://doi.org/10.1016/j. autrev.2019.102350

27. Cantorna MT, Mahon BD. Mounting evidence for vitamin $D$ as an environmental factor affecting autoimmune disease prevalence. Exp Bioi Med 2004;229:1136-42. https://doi. org/10.1177/153537020422901108

28. Holick MF. Sunlight and vitamin D for bone health and prevention of autoimmune diseases, cancers, and cardiovascular disease. Am J Clin Nutr 2004;80:1678S-88S. https://doi.org/10.1093/ ajcn/80.6.1678S

29. Marques CDL, Dantas AT, Fragoso TS, Duarte ALBP. The importance of vitamin $D$ levels in autoimmune diseases. Bras $\mathrm{J}$ Rheumatol 2010;50(1):67-80. https://doi.org/10.1590/S048250042010000100007

30. Illescas-Montes R, Melguizo-Rodriguez L, Ruiz C, Costela-Ruiz VJ. Vitamin D and autoimmune diseases. Life Sci 2019;233:116744. https://doi. org/10.1016/j.lfs.2019.116744

31. Croker JA, Kimberly RP. SLE: challenges and candidates in human disease. Trends Immunol 2005;26(11):580-6. https://doi.org/10.1016/j. it.2005.09.001

32. Iruretagoyena M, Hirigoyen D, Naves R, Burgos $\mathrm{PI}$. Immune response modulation by vitamin D: Role in systemic lupus erythematosus. Front Immunol 2015;6:513. https://doi.org/10.3389/ fimmu.2015.00513

33. Attar SM, Siddiqui AM. Vitamin D deficiency in patients with systemic lupus erythematosus. Oman Med J 2012;28(1):42-7. https://doi.org/10.5001/ omj.2013.10

34. Kamen DL. Vitamin D in Lupus: New kid on the block? Bull NYU Hosp Jt Dis 2010;68(3):218-22.

35. Schoindre $\mathrm{Y}$, Jallouli $\mathrm{M}$, Tanguy $\mathrm{ML}$, Ghillani $\mathrm{P}$, Galicier L, Aumaitre O, et al. Lower vitamin D levels are associated with higher systemic lupus erythematosus activity, but not predictive of disease flare-up. Lupus Sci Med 2014;1 (1):e000027. https://doi.org/10.1136/lupus-2014-000027

36. Robinson $A B$, Thierry-Palmer M, Gibson KL, Rabinovich CE. Disease activity, proteinuria, and vitamin $D$ status in children with systemic lupus erythematosus and juvenile dermatomyo- sitis. J Pediatr 2012;160(2):297-302. https://doi. org/10.1016/j.jpeds.2011.08.011

37. Borba VZ, Vieira JG, Kasamatsu T, Radominski SC, Sato El, Lazaretti-Castro M. Vitamin D deficiency in patients with active systemic lupus erythematosus. Osteoporos Int 2009;20(3):42733. https://doi.org/10.1007/s00198-008-0676-1

38. Petri M, Bello KJ, Fang H, Magder LS. Vitamin $D$ in systemic lupus erythematosus: modest association with disease activity and the urine protein-to-creatinine ratio. Arthritis Rheum 2013;65(7):1865-71. https://doi.org/10.1002/ art.37953

39. Schneider L, Dos Santos AS, Santos M, da Silva Chakr RM, Monticielo OA. Vitamin D and systemic lupus erythematosus: state of the art. Clin Rheumatol 2014;33(8):1033-8. https://doi.org/10.1007/ s10067-014-2530-5

40. Embry AF, Snowdon LR, Vieth R. Vitamin D and seasonal fluctuations of gadolinium-enhancing magnetic resonance imaging lesions in multiple sclerosis. Annals Neurol 2000;48(2):271-2. https://doi. org/10.1002/1531-8249(200008)48:2<271::AIDANA28 > 3.0.CO;2-O

41. Soilu-Hanninen M, Airas L, Mononen I, Heikkila A, Viljanen M, Hanninen A. 25-Hydroxyvitamin $D$ levels in serum at the onset of multiple sclerosis. Mult Scler 2005;11(3):266-71. https://doi. org/10.1191/1352458505ms1157oa

42. Sintzel MB, Rametta M, Reder AT. Vitamin D and multiple sclerosis: A comprehensive review. Neurol Ther 2018;7(1):59-85. https://doi.org/10.1007/ s40120-017-0086-4

43. Alharbi FM. Update in vitamin $\mathrm{D}$ and multiple sclerosis. Neurosciences (Riyadh) 2015;20(4):329-35. https://doi.org/10.17712/nsj.2015.4.20150357

44. Mansouri B, Asadollahi S, Heidari K, Fakhri M, Assarzadegan F, Nazari M, et al. Risk factors for increased multiple sclerosis susceptibility in the Iranian population. J Clin Neurosci 2014;21 (12):2207-11. https://doi.org/10.1016/j. jocn.2014.04.020

45. Bjornevik K, Riise T, Casetta I, Drulovic J, Granieri E, Holmoy T, et al. Sun exposure and multiple sclerosis risk in Norway and Italy: The EnvIMS study. Mult Scler 2014;20(8):1042-9. doi: $10.1177 / 1352458513513968$ https://doi. org/10.1177/1352458513513968

46. Lucas RM, Ponsonby AL, Dear K, Valery PC, Pender MP, Taylor BV, et al. Sun exposure and vitamin $D$ are independent risk factors for CNS demyelination. Neurology 2011;76:540-8. https:// doi.org/10.1212/WNL.0b013e31820af93d

47. Vander-Mei IAF, Ponsonby AL, Dwyer T, Blizzard L, Simmons R, Taylor BV, et al. Past exposure to sun, skin phenotype, and risk of multiple sclerosis: case-control study. BMJ 2003;327:1-6. https:// doi.org/10.1136/bmj.327.7410.316

48. Muris AH, Rolf L, Broen K, Hupperts R, Damoiseaux J, Smolders J. A low vitamin D status at diagnosis is associated with an early conversion 
to secondary progressive multiple sclerosis. $\mathrm{J}$ Steroid Biochem Mol Biol 2016;164:254-7. https:// doi.org/10.1016/j.jsbmb.2015.11.009

49. Ashtari F, Toghianifar N, Zarkesh-Esfahani SH, Mansourian M. High dose Vitamin D intake and quality of life in relapsing-remitting multiple sclerosis: a randomized, double-blind, placebo-controlled clinical trial. Neurol Res 2016;38(10):88892. https://doi.org/10.1080/01616412.2016.12 27913

50. Harris SS. Vitamin D in Type 1 Diabetes prevention. J Nutr 2005;135:323-5. https://doi. org/10.1093/jn/135.2.323

51. Bener A, Alsaied A, Al-Ali M, Al-Kubaisi A, Basha B, Abraham A, et al. High prevalence of vitamin D deficiency in type 1 diabetes mellitus and healthy children. Acta Diabetol 2009;46(3):183-9. https:// doi.org/10.1007/s00592-008-0071-6

52. Dong JY, Zhang WG, Chen JJ, Zhang ZL, Han SF, Qin LQ. Vitamin D intake and risk of type 1 diabetes: a meta-analysis of observational studies. Nutrients 2013;5(9):3551-62. https://doi. org/10.3390/nu5093551

53. Schwalfenberg G. Vitamin D and diabetes. Can Fam Physician 2008;54:864-6.

54. Aljabri KS, Bokhari SA, Khan MJ. Glycemic changes after vitamin $D$ supplementation in patients with type 1 diabetes mellitus and vitamin $D$ deficiency. Ann Saudi Med 2010;30(6):454-8. https://doi. org/10.4103/0256-4947.72265

55. Sharma S, Biswal N, Bethou A, Rajappa M, Kumar $S$, Vinayagam V. Does vitamin D supplementation improve glycaemic control in children with type 1 diabetes mellitus? - a randomized controlled trial. J Clin Diagn Res 2017;11(9):SC15-SC7. https:// doi.org/10.7860/JCDR/2017/27321.10645

56. Gregoriou E, Mamais I, Tzanetakou I, Lavranos $G$, Chrysostomou S. The effects of vitamin D supplementation in newly diagnosed type 1 diabetes patients: Systematic review of randomized controlled trials. Rev Diabet Stud 2017;14(2-3):260-8. https://doi.org/10.1900/RDS.2017.14.260

57. Gubatan J, Moss AC. Vitamin D in inflammatory bowel disease: more than just a supplement. Curr Opin Gastroenterol 2018;34(4):217-25. https:// doi.org/10.1097/MOG.0000000000000449

58. Cantorna MT, Munsick C, Bemiss C, Mahon BD. 1,25-dihydroxycholecalciferol prevents and ameliorates symptoms of experimental murine inflammatory bowel disease. J Nutr 2000;130:2648-52. https://doi.org/10.1093/jn/130.11.2648

59. Daniel C, Radeke HH, Sartory NA, Zahn N, Zuegel $U$, Steinmeyer A, et al. The new low calcemic vitamin D analog 22-ene-25-oxa-vitamin D prominently ameliorates $T$ helper cell type 1-mediated colitis in mice. J Pharmacol Exp Ther 2006;319(2):62231. https://doi.org/10.1124/jpet.106.107599

60. Kikuchia H, Murakamid S, Suzuki S, Kudo H, Sassa S, Sakamoto S. Chemopreventive effect of a vitamin D3 analog, alfacalcidol, on colorectal carcinogenesis in mice with ulcerative colitis.
Anti-Cancer Drugs 2007;18:1183-7. https://doi. org/10.1097/CAD.0b013e3282eea468

61. Fletcher J, Cooper SC, Ghosh S, Hewison M. The role of vitamin $D$ in inflammatory bowel disease: Mechanism to management. Nutrients 2019;11(5):1019. https://doi.org/10.3390/ nu11051019

62. Cecchetti S, Tatar Z, Galan P, Pereira B, Lambert C, Mouterde G, et al. Prevalence of vitamin D deficiency in rheumatoid arthritis and association with disease activity and cardiovascular risk factors: data from the COMEDRA study. Clin Exp Rheumatol 2016;34(6):984-90.

63. Kostoglou-Athanassiou I, Athanassiou P, Lyraki A, Raftakis I, Antoniadis C. Vitamin D and rheumatoid arthritis. Therc Adv Endocrinol Metab 2012;3(6):181-7. https://doi. org/10.1177/2042018812471070

64. Bragazzi NL, Watad A, Neumann SG, Simon M, Brown SB, Abu Much A, et al. Vitamin D and rheumatoid arthritis: an ongoing mystery. Curr Opin Rheumatol 2017;29(4):378-88. https://doi. org/10.1097/BOR.0000000000000397

65. Hajjaj-Hassouni N, Mawani N, Allali F, Rkain $\mathrm{H}$, Hassouni K, Hmamouchi I, et al. Evaluation of vitamin D status in rheumatoid arthritis and its association with disease activity across 15 countries: "The COMORA study". Int J Rheumatol 2017;2017:5491676. https://doi. org/10.1155/2017/5491676

66. Meena N, Singh Chawla SP, Garg R, Batta A, Kaur $S$. Assessment of vitamin $D$ in rheumatoid arthritis and its correlation with disease activity. J Nat Sci Biol Med 2018;9(1):54-8. https://doi.org/10.4103/ jnsbm.JNSBM_128_17

67. Aslam MM, John P, Bhatti A, Jahangir S, Kamboh MI. Vitamin D as a principal factor in mediating rheumatoid arthritis-derived immune response. Biomed Res Int 2019;2019:3494937. https://doi. org/10.1155/2019/3494937

68. Harrison SR, Li D, Jeffery LE, Raza K, Hewison M. Vitamin D, Autoimmune Disease and Rheumatoid Arthritis. Calcif Tissue Int 2020;106(1):58-75. https://doi.org/10.1007/s00223-019-00577-2

69. Brink M, Johansson L, Nygren E, Ärlestig L, Hultdin J, Rantapää-Dahlqvist S. Vitamin D in individuals before onset of rheumatoid arthritis - relation to vitamin $\mathrm{D}$ binding protein and its associated genetic variants. BMC Rheumatol 2018;2:26. https://doi.org/10.1186/s41927-018-0033-8

70. Reins RY, McDermott AM. Vitamin D: Implications for ocular disease and therapeutic potential. Exp Eye Res 2015;134:101-10. https://doi. org/10.1016/j.exer.2015.02.019

71. Grotting LA, Davoudi S, Palenzuela D, Papaliodis GN, Sobrin L. Association of low vitamin D levels with noninfectious anterior uveitis. JAMA Ophthalmology 2017;135(2):150-3. https://doi. org/10.1001/jamaophthalmol.2016.4888

72. Chiu ZK, Lim LL, Rogers SL, Hall AJ. Patterns of vitamin $D$ levels and exposures in active and in- 
active noninfectious uveitis patients. Ophthalmology 2020;127(2):230-7. https://doi.org/10.1016/j. ophtha.2019.06.030

73. Valdez M, Mirthi AT, Francisco MT, Maldonado M, Lopez M, Montalvo I, et al. Autoimmune uveitis: A pilot study of vitamin D levels and its supplementation effect. Invest Ophthalmol Vis Sci 2014;55(13):93-.

74. Sengler C, Zink J, Klotsche J, Niewerth M, Liedmann I, Horneff G, et al. Vitamin D deficiency is associated with higher disease activity and the risk for uveitis in juvenile idiopathic arthritis - data from a German inception cohort. Arthritis Research \& Therapy 2018;20(1):276. https://doi. org/10.1186/s13075-018-1765-y

75. Murphy $\mathrm{G}$, Reich K. In touch with psoriasis: topical treatments and current guidelines. J Eur Acad Dermatol Venereol 2011;25 Suppl 4:3-8. https:// doi.org/10.1111/j.1468-3083.2011.04059.x

76. Ashcroft DM, Po ALW, Williams HC, MGriffiths CE. Systematic review of comparative efficacy and tolerability of calcipotriol in treating chronic plaque psoriasis. BMJ 2000; 327: 963-7. https:// doi.org/10.1136/bmj.320.7240.963

77. Mesquita KC, Igreja AC, Costa IM. Atopic dermatitis and vitamin D: facts and controversies. An Bras Dermatol 2013;88(6):945-53. https://doi. org/10.1590/abd1806-4841.20132660

78. Karagun E, Ergin C, Baysak S, Erden G, Aktas H, Ekiz O. The role of serum vitamin $D$ levels in vitiligo. Postepy Dermatol Alergol 2016;33(4):300-2. https://doi.org/10.5114/pdia.2016.59507

\begin{tabular}{c} 
CONFLICT OF INTEREST \\
Authors declare no conflict of interest. \\
GRANT SUPPORT AND FINANCIAL DISCLOSURE \\
Grant No. G-103-2020, Deanship of Scientific Research, \\
University of Hafr Al Batin \\
\hline
\end{tabular}

\section{AUTHORS' CONTRIBUTION}

The following authors have made substantial contributions to the manuscript as under:

Conception or Design:

Acquisition, Analysis or Interpretation of Data:

Manuscript Writing \& Approval:

All the authors agree to be accountable for all aspects of the work in ensuring that questions related to the accuracy or integrity of any part of the work are appropriately investigated and resolved.

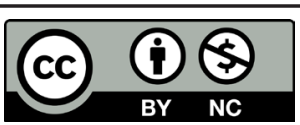

Copyright (C) 2020. Farhan Khashim Alswailmi, et al. This is an Open Access article distributed under the terms of the Creative Commons Attribution-NonCommercial 4.0 International License, which permits unrestricted use, distribution \& reproduction in any medium provided that original work is cited properly. 